\title{
Lies in Plato's Republic: poems, myth, and noble lie
}

\author{
YU-JUNG SUN \\ Université de Paris 1, Sorbonne \\ sun.yujung@gmail.com
}

\begin{abstract}
Recibido: 07/06/2017 - Aceptado: 24/11/2017
DOI: https://doi.org/10.20318/fons.2017.3860
\end{abstract}

\begin{abstract}
In this paper, I argue that 1) the ostensible inconsistency between the judgments of value on different kinds of lying, like poetry, fabricated story, myth and noble lies, is not a veritable one, and 2) Plato does not hold a utilitarian position on the question of lying, or making up something false to be more precise, and lies do not turn into noble lies once they are told to be in the service of some superior purpose. Plato

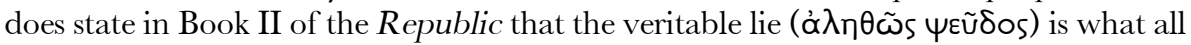
gods and all man hate (382a), and poets must be punished for deceiving people by linking the Supreme Being to its contrary. But Plato also discusses the useful lie, especially the one lie that is necessary for the unity and stability of the polis: the Noble Lie. Neither useful lies nor noble lies can be acceptable just because we can make a use out of it, and it does not hold either that the greater the use we can make out of a lie, the

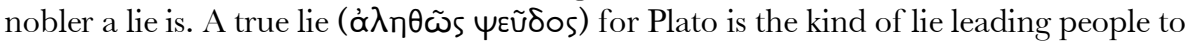
believe that the hierarchy of the forms can be reordered in any way, and we can make random associations between the forms, like forming the relation between gods and the action of war. On the other hand, useful lies and the noble lies are in fact a duplicate of the order of the forms. This order, which articulates forms, is what makes thinking of truth possible, and we can later find this idea of the order of the forms which allows us to think truth and falsity in both the Theaetetus and the Sophist.
\end{abstract}

Keywords: Lie, imitation, dialectic, falsehood

\section{Introduction}

Lies assume numerous forms in Plato's dialogues, particularly in the Republic. Plato's discussion on lies in the Republic raises more questions than he answers. Since in the Republic Plato makes Socrates explicitly claims that 
"some lies can be useful"1 (382c6) it seems natural that the majority of the interpreters of Plato treat his position on lies as a utilitarian one ${ }^{2}$, and therefore argue that poets are banished from the polis because they are harmful to the polis and that the nobility of the noble lie lies in the efficacy of the utility that it produces. I will argue against this utilitarian interpretation of lie in the Republic later in this paper.

In Plato's discussion, two questions arise with the problem of lies: the question regarding falsehood and its relation to the truth, and the question that asks

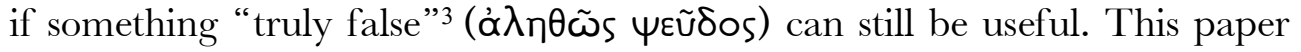
tries to answer principally these two questions in order to understand Plato's analysis and position on lies, or his own term, $\psi \varepsilon \cup{ }^{\prime} \delta \omega$ and all its derivation, which means "making something false". From today's point of view, the relation between truth and falsehood is generally considered ambivalent and under the law of excluded middle. Therefore, all lies are equally false, and the only difference between the lies that we can accept in the ideal republic and the ones that must be rejected is whether it is useful or harmful, a criterion that does not involve the truth/falsehood of the lie. But this inference leads to the following incoherent conclusions: 1) lies are hateful unless they are useful; 2) the birth of a republic relies on one essential lie, "the noble lie," that ensures the solidarity between the classes in the republic, and 3) the philosopher king must love the truth and hate all kinds of lie.

So, if all lies are excluded from the truth for Plato, then the treatment of lies in the Republic compromises the integrity of the dialogue. In order to avoid this consequence, we need to examine the possibility that for Plato something can be both true and false, and this examination requires reconsideration of the definition of truth, falsehood and the relation between them. Instead of claiming that there exist two senses of falsehood for Plato like Létitia Mouze

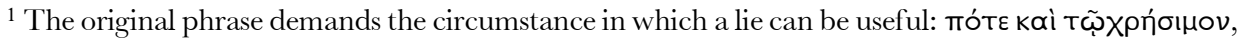

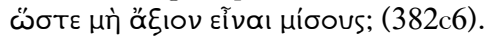

${ }^{2}$ Commentators like Mouze argue that the question of lies in the Republic, particularly in the book II and III are about utility and not about truth, as she says: «Les critères en function desquels les textes sont sélectionnés sont instructifs. Apparemment, et pour un certain nombre de commentateurs, le critère est celui de la vérité, de la conformité du discours à son objet, à ce qui est. Pourtant, à y regarder de plus près, il ne s'agit nullement ici de vérité» (MouZE 2005, p. 24).

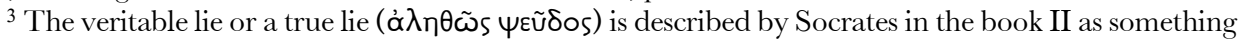
"hated by human being and also by gods" (Republic 382c3, my translation).

${ }^{4}$ Mouze claims that there are two senses of falsehood revealed in the Book II and III of the Republic. The first sense of falsehood consists of the kind of discourse that is impossible to verify its truthfulness, like the discourse about imaginary things, gods, past that we cannot trace etc. When it is impossible to
} 
I propose a hypothesis that there are not two different senses of falsehood and thus require two criteria of falsehood; instead, I argue that there are different degrees of falsehood in accordance with their relations to truth and how Plato distinguishes two in the Republic.

My thesis of this article is that for Plato, it is not the utility or the harm but their degrees of falsehood that serve as the criterion of separating good lies from bad ones. In order to demonstrate how this "degrees of falsehood" thesis is developed in the Republic, I will first analyze the discussion on lies in Book II and Book III. Second, to extend the question of imitation raised in Book III, I refer to the Sophist to answer this question: what makes a false discourse a lie? Finally, I will explain how the distinction between the "lie in words"

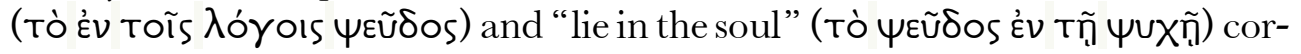
responds to the distinction between degrees of falsehood.

\section{Plato's Analysis of lie in Book II and Book III of the Republic}

Considering the ambiguous translation of the word $\psi \varepsilon \cup \tilde{\text { Ũ }}$ os and all its derivation in verb, adjective and noun form, it needs to be clarified that this paper focuses on the discussion around the passages where Plato employs the term with the radical $\psi \varepsilon \tilde{\widetilde{\delta}}-$, no matter if it is translated by "lie", "fiction"5, "false speech or discourse" or "false story". Since in the Republic that the person who uses the false discourse is aware of its falsity, or at least aware of its state of not-being-absolutely-real, I use the term "lie" to cover all usages of $\psi \in \tilde{u} \delta$ os in the Republic in a uniform way for now and propose a classification later in the article.

verify the truth/falsehood of the discourse, that is, if the discourse corresponds to the reality, in this case, the criterion of truth/falsehood is its utility. On the other hand, when the truth/falsehood of the discourse is verifiable, the criterion of truth is the existence of a certain fact, which corresponds to its description. This distinction between two senses of falsehood presuppose that the reality to which the discourse refers to is understood by the sensible reality through which we can verify by empirical facts. I disagree with Mouze's point of view. If Plato does support two criteria of truth/falsehood, then, the discourses of sophists can be truth since it could be truth-unverifiable but useful. Even if we want to define the truth by a very specific kind of utility, for example, the common good, we need to be capable of determine the exact utility the discourse can bring and justify it. The discourse which determine and justify the utility must be whether a discourse that corresponds to a verifiable fact or another utility. The former case leads this argument into a circle and the later into infinite regress.

${ }^{5}$ Emlyn-Jones, Preddy translate the passage of storytelling in $377 \mathrm{a}$ as: «And there are two kinds of story: true ones and fictional?» to emphasize the «moral value of fictions rather than their literal truthvalue: as S. says about the muthoi (fables) in 377a4-5» (EMLYN-JONES, PREDDy 2013, p. 192). 
At the end of Book II of the Republic, Socrates starts to examine the first phase of guardian training, which is the education for the children who are to be the future guardians. The guardians of the polis ought to be trained both physically, which aims at the body, and intellectually, which targets the soul. The formation of the guardians' soul, according to Socrates, can start with storytelling; false storytelling, to be exact, as he states:

«And there are two kinds of discourses; true ones and false ones?»

«Yes»

«We must educate them in both kinds, but false discourse first. Mustn’t We?»6${ }^{6}(376 \mathrm{e} 11)$

The idea of storytelling as a part of guardian training is to forge and to leave certain marks on the soul of these children in order to make them believe in certain things and develop correct opinions without understanding why. The effect that a story evokes in the soul is crucial to the training program, and it is precisely this effect that determines which kind of false story should be told to the future guardian. Lies here are meant to achieve an educational end, as what Page defines as "paedeutic lie" ". Nevertheless, it doesn't mean that the effect produced by storytelling has absolutely nothing to do with its truth/falsehood. Socrates provides several examples of different kinds of lies that do not satisfy the criterion of the paedeutic lie, and hence are just lies. In the following passage, I try to demonstrate that the reason why some lies are more hateful than others consists of the severity of its falsehood.

Mouze distinguishes three kinds of discourses in the passage 377e1-392d3: the discourse on gods, the discourse on heroes and Hades and the discourse on men. This distinction serves to demonstrate that there are two senses of falsehood. According to Mouze, the first sense of falsehood corresponds to the falsehood in the discourse on gods and on heroes, because the truth/falsehood of this kind of discourse is determined by its potential utility since its truth/falsehood cannot be verified. The second sense of falsehood corresponds to the discourse of the third kind, the discourse on men, because its falsehood, for Mouze, is determined by whether the discourse corresponds to the reality or not, since the truth/falsehood of its content can be verified ${ }^{8}$. Here, I modify the distinction proposed by Mouze, and analyze this passage by classifying the

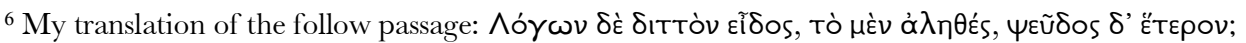

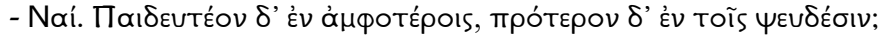

${ }^{7}$ PAGe 1991, p. 15; DOMBROWSKi 2004, p. 95.

${ }^{8}$ Mouze 2005, pp. 24-32. 
examples into three kinds of lies: lies about gods, lies about the past, and lies about men. I change the second kind of discourse into lies about the past, instead of those of heroes and Hades, in order to distinguish the discourses by type and not by subject: lies about gods, lies about the past and the lies about men.

What needs to be clarified here is that the "lies about heroes" are discourses which concern the past. From most people's point of view, the past must refer to reality in the past that is recorded in the written history, so there should be some sort of objective truth of the past which serves to be the reference of truth/falsehood. Nonetheless, I attempt to show that the "discourse about the past" concerns all description of the changing world, and since history in that time is passed on by stories and mythologies around the real historical figures, or the "heroes," it is not pertinent to suppose that there should be a kind of discourse whose truth/falsehood is determined by it historical truth. That is the reason why in my classification of the three kinds of lies, the stories around Hades are categorized in the "discourse about the past." In this way, my distinction of three kinds of lies correspond conceptually to Supreme Being (perfect), changing world (imperfect and no direct access to its reality), and affair of contemporary men (mutable and relatively has access for its reality) as object of lie.

\section{a) Lies about gods}

Socrates gives three examples of the lies about gods which should never be told to children. For Socrates, stories about the "war between gods" 9 and any "hostile act"10 from gods should not be told, because "good cannot be the cause of bad":

A god is, of course, good in reality and must be spoken as such? [...]

Good is not responsible for everything, only for those things which are good, not those which are bad?

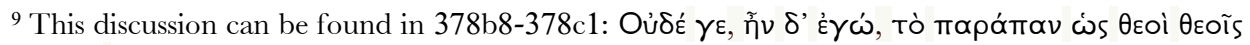

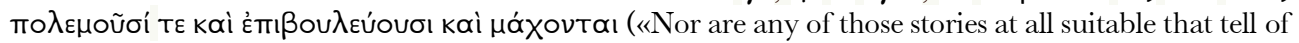
the gods making war, plotting against and fighting other gods». Translation of EMLYN-JONES, PREDDY 2013).

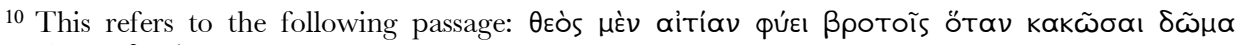
$\pi \propto \mu \pi n ́ \delta \eta \nu ~ \theta \varepsilon ́ \lambda \eta ̣$ («For mortals god implants guilt. Whenever he wishes to ruin a house utterly», 380a23, translation of EMLYN-JONES, PREDDY 2013).
} 
Then since he is good[...]no one else is to be held responsible for the good things, but for the bad things we must look for any other cause but the $\operatorname{god}^{11}$. (379b1-379c8)

This is a simple logical argument, the inference of which is very hard to contradict, and it corresponds perfectly to a standard syllogism:

God is good,

good is the cause of good things and not of bad things,

Therefore, god cannot be the cause of bad things.

The third example of the lies about gods concerns the kind of storytelling that god metamorphoses so as to make us believe or deceive us that he is something else ${ }^{12}$. These lies must be avoided because:

Everything that is in a good state, naturally, artificially or both, undergoes the least change by an external force.

There again god and everything that pertains to god is in excellent condition in every way.

Then it is impossible even for a god to want to change himself. But every one of them, it seems, being the best and finest possible, always remains simply in their own shape ${ }^{13}$. (381b1-c9)

Socrates doesn't just give random reasons to justify the fact that the story about gods can changing forms must be false and must be a true lie. Instead, he provides an inference from the relations between intelligible forms, which derive a conclusion which refutes this kind of story.

The inference here works as follows:

All changes are for the better,

God is by definition the perfect being,

Therefore, gods cannot change into other forms (since he is already the best).

A utilitarian argument would claim that this kind of discourse needs to be banned because, if gods can be the cause of bad things, there is no reason to be

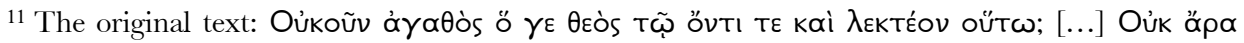

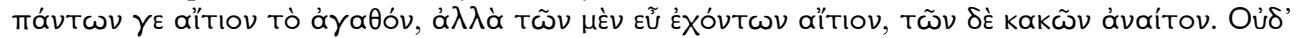

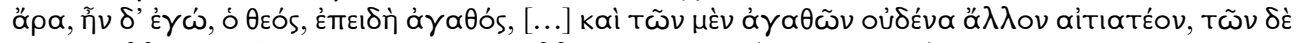

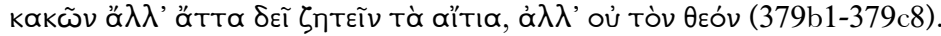

${ }^{12}$ Here refers to the following passage: «Do you think god is a wizard and the sort who treacherously makes himself visible sometimes in one form, sometimes in another, and then again becoming himself, changing his appearance into many forms, then deceiving us and making us believe he has done so?»

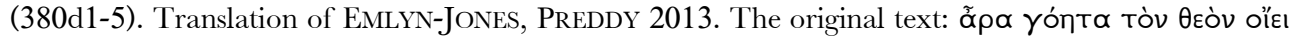

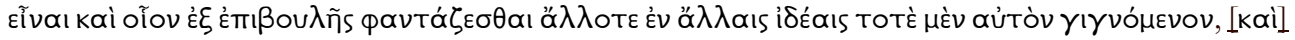

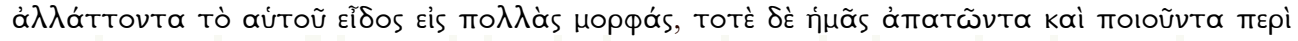

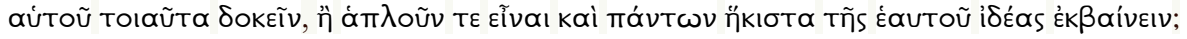

13 Translation of Emlyn-Jones, PREdDy 2013, pp. 209-211. 
good and act out of goodness, and this belief jeopardizes the polis ${ }^{14}$. From an ostensibly utilitarian viewpoint, the falsehood of this kind of discourse is determined by the harm it could do in the republic since, according to Mouze, the reality of mythology or stories about gods are not verifiable ${ }^{15}$ and for Gill, there is some truth that is "supposed to be true" ${ }^{16}$. Nonetheless, all of the three examples illustrate that the falsehood of these stories about gods, which makes them a lie, is not determined by their utility but by a derivation from the fixed relations between notions. Perfection and goodness are the essential constituent in the notion of god, and the notion of god is determined by the form of goodness. If we allow stories informing us that a god can do something considered bad or that god can change into lesser forms, then it is equivalent to agreeing that good is bad and perfect imperfect, causing contradiction in thought and perhaps harm the interest of the republic. That is the reason why Socrates calls this kind of lie the "true lies" or what is "truly false" ( $\alpha \lambda \eta \theta \tilde{\theta} \varsigma$ భ $\Psi \tilde{\cup} \delta \circ \varsigma$ ) instead of an "evil lie" which emphasizes more on the effect of the lie:

\footnotetext{
"But does that mean a god would be willing in word or deed to falsify himself by presenting an apparition to us?"

"I don't know," he said.

"Don't you know," I asked, "that all gods and men hate the true lie if one may put it like that?"17 (381e8-382a5)
}

The term å $\lambda \eta \theta \tilde{\omega} \varsigma$ $\psi \varepsilon \tilde{u} \delta$ os appears only twice in the Republic, and since it is often translated differently ${ }^{18}$, it may not be evident to understand that this term actually reveals a kind of lie which introduces nothing but ignorance in the soul because of the total absence of truth. As Socrates states:

${ }^{14}$ This is the argument proposed by Mouze 2005, p. 25.

${ }^{15}$ Mouze 2005, p. 31.

${ }^{16}$ Gill claims that «it makes sense to distinguish between what is supposed to be true and what is in fact true. The distinction drawn in 382a-c presupposes that there are objective truths as regards 'the most important things'...» (GILL 1993, p. 48). The distinction here presupposes the existence of some kind of morally objective truth, and for Gill, this is the reason why even all myths are false, certain are bad in the sense of being morally false.

17 Translation of EMlyn-Jones, PRedDy 2013.

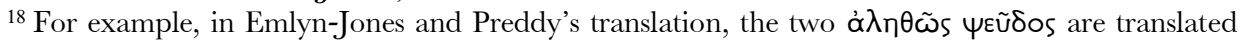
individually into "true lie" and "true falsehood": « that all gods and men hate the true lie if one may put it like that? » (382a4-5) and «as I was just saying, what would be most rightly called a true falsehood is the ignorance in the soul of the one who has been deceived» $(382 \mathrm{~b} 8)$. 
What would be most rightly called a true lie, as what I was saying, is the ignorance in the soul of the one who has been deceived ${ }^{19}$. $(382 \mathrm{~b} 7-8)$

So, the lies about gods are true lies and are truly false because they introduce contradiction by conjoining contradictory ideas, for example, god and bad or god and imperfect. The consequence of putting contradictory ideas in children's head is not commensurable with the potential detriments to the collective interest; the former leads to the confusion in the soul and the latter causes damage by bringing the belief into action. Socrates does not define these stories as "true lies" by proving their falsity because of the gravity of the harm they can cause, but because they lead to contradiction by combining the concepts which do not consist with each other ${ }^{20}$. The effect of "true lies" on the soul is later opposed to another kind of lie which has its effect mainly on words that Plato calls "lie in words". I will return to this contrast between "true lies" or "lies in the soul" and "lies in words" in the next section.

\section{b) Lies about the past}

These examples that Socrates draws concern heroes. Socrates claims that we should not tell stories about those we call heroes in fear of death because the guardians of the republic must have the courage against the death in mind $^{21}$. It seems difficult to defend this thesis against the utilitarian interpretation since Socrates proclaims clearly that this kind of stories are lies and should not be told because they might render our guardians "feverish and softer than we think they should be" 22 (387c5). But if we examine Socrates' claim more closely, we can still find an argument resembling that on the lies about gods I discuss above. Below is the argument that Socrates gives to justify why we

\footnotetext{
${ }^{19}$ My translation. I translate all usage of $\alpha \lambda \eta \theta \tilde{\omega} s \psi \varepsilon \tilde{\delta} \delta$ os as "true lie" in order to demonstrate it as a term which denotes the kind of lie which introduces only ignorance and ignorance alone in the soul of

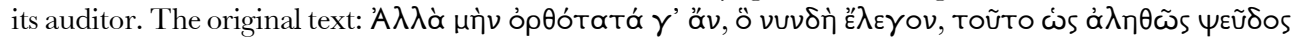

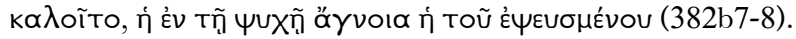

${ }^{20}$ In the Sophist, Plato claims that there are kinds which communicate with each other and those which do not, and that is how we can determine a kind by what it communicate with (the self) and what it does not communicate with (the other).

${ }^{21}$ Socrates explains this in the passage 386a6-387c5.

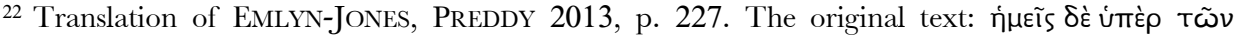

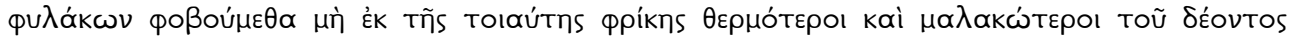

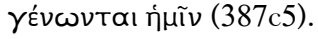


should remove the stories about heroes fearing death or good man pitying those who die 23 :

- We do say that the good man does not consider death fearful for the good man, even if he is his comrade-in-arms.

- Then he would not mourn for that man as if he has suffered something fearful.

- But we also say this, that such a one is most of all men sufficient to himself for a good life and is distinguished from other men in having least need of anybody else.

- Least of all then to him is it a terrible thing to lose son or brother or his wealth or anything of the sort ${ }^{24}$. (387d4-6)

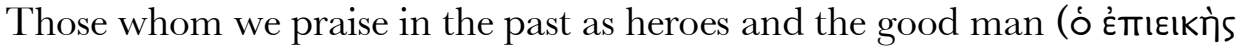
ávìp) of the society represent the idea of courage defying death and the idea of self-sufficiency as opposed to the attachment. "Hero" and "good man" do not refer to someone characterized by the supreme good and perfection like god, but someone characterized by courage or self-sufficiency. Telling a story about heroes or good man mourning for their lost equals telling a true lie, because the act of mourning for the lost is incompatible with the idea of "courage" and "self-sufficiency". Claiming that heroes fear death or the good man mourning for his or her lost are equivalent to affirming "the courage defying death fears death" and "self-sufficiency is dependent".

\section{c) Lies about men}

The last type of lie concerns not heroic figures but mankind in general; in other words, it concerns every individual in the polis. The example Socrates provides is to tell stories depicting unjust people enjoying happiness while just people being deprived of happiness ${ }^{25}$.

In appearance, it seems difficult to assert that "justice" and "happiness", share common implications, and that the form of justice implies in some way the idea of happiness. According to $\mathrm{Mouze}^{26}$, the implication stands because

23 "We shall also remove the lamentations and pitiful wailing of famous men?" (Kaì toùs ódupuoùs

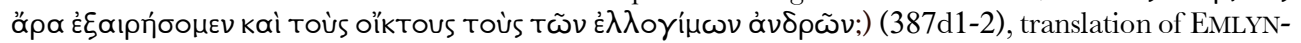
JONES, PREDDY 2013, p. 227). We can see that Socrates does not only want to remove the kind of story about heroes' fear for death, but also the kind that talks about the lamentation for the dead.

24 Translation of EmLYN-Jones, PRedDy 2013, p. 227.

${ }^{25}$ Here I refer to this passage: "Because I think that we shall say that both poet and prose authors get it wrong about mankind in matters of the greatest importance, that many of those who are happy are unjust...", translated by EMLYN-JONES, PREDDY 2013, p. 247.

${ }^{26}$ Mouze claims that the lie about man is the only kind which shares the same criterion of truth/falsehood that we often use today, which is: the correspondence between proposition and reality observed. 
Plato employs another criterion of truth/falsehood. It does seem that it is itself a lie to consider the statement "just man is happy" a lie; this statement urges people to act on justice for the sake of the common interest. Socrates' following statement allows us to rethink the possibility that the problem here always concerns the relations between notions:

These are the kind of stories which must be told about men only when we discover what kind of thing justice is and that it is naturally profitable for the person who has it whether in fact, he seems to be a just man or not ${ }^{27}$. (392c)

That "unjust man is happy" is a lie, but saying "just man is happy," according to Socrates, is the kind of stories which must be told only when we can answer what justice is. There may neither be a direct logical relevance nor a semantical affinity between "justice" and "happiness." Nevertheless, later in the Republic and in other dialogues, Plato demonstrates how the two notions merge together in the action and shows that there is a connection between them when searching the answer to "what justice is" and "what happiness is" 28 . This connection between justice and happiness demonstrates that the relations between concepts that I have explained earlier are neither "logical" (so not in the form of the proposition) nor "semantical" (not about the literal meaning of the terms), but "dialectical" since it is about the articulation of intelligible forms. As we can see in this example, the connection between justice and happiness cannot be established before we clarify how these two forms articulate in relation to other forms, like goodness, beauty, virtue, knowledge, pleasure etc.

According to Mouze, "just man is happy" is the only kind of discourse that we can verify by experience, and it is a lie to tell stories like "unjust man being happy" because it does not correspond the reality that we can observe. In reality, we actually have the impression which contradicts the Mouze's observation, that is, we often have an impression that people who seems to be just seems to be in unhappiness, and people who appeared to be unjust seems to enjoy the happiness (MOUZE 2005, pp. 27-31).

27 Translation of Emlyn-Jones, Preddy 2013, p. 247. The original text: Oủkoũv $\pi \varepsilon p i ́ ~ \gamma \varepsilon ~ \alpha ُ v \theta \rho \omega ́ \pi \omega \nu$

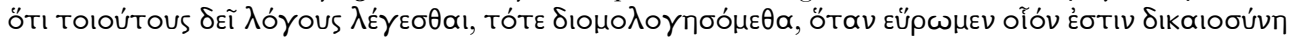

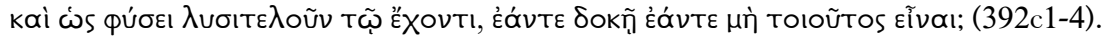

${ }^{28}$ The relation between justice and happiness is one of the most discussed problems in the Republic. In the Devereux's article, the debates on this question are well presented from the first one between FosTER 1937 and 1938 and MABBOTT 1937 which started the discussion on justice and happiness. The debates around the relation between the content of justice and happiness give rise to numerous hypotheses, some of which claim that for Plato, happiness is the consequence of justice while other of which claim that they only have a relation so close that the manifestation of one manifests the other. Destrée claims that the connection between justice and happiness is assured and linked by the form of goodness (Altman 2012; Destrée 2010, p. 252; DevereuX 2005). 
With the distinction of these three kinds of lies, we can see that a hierarchical difference exists between the three kinds. Lies about gods are the vilest because it consists the kind of lie that disrupts the relations between the pure forms, since "god" is identical to the form "goodness."

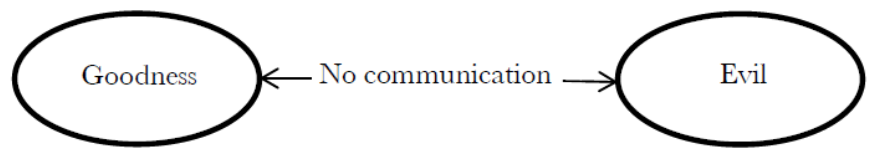

Secondly, lies about the past is about the "good person" or the "bad person" who abides by the forms "goodness" or "evil," and its falsehood derives from the disorder in the participation of the different forms, that is why it is about the compatibility of the participation of forms. That is, a participant of goodness should also participate in the courage.

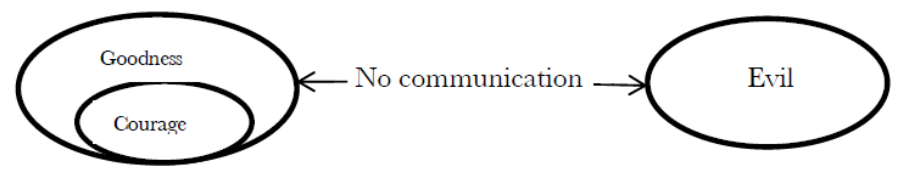

And finally, the third kind of lies about men is a lie because the participant of the form "justice" is necessary a participant of the form "goodness," should not participate the form "unhappiness."

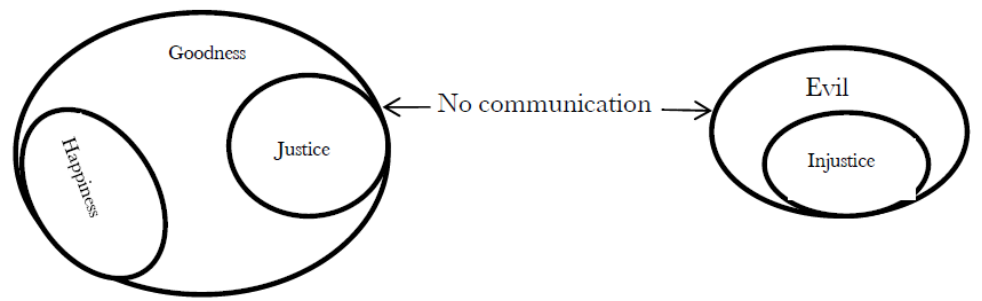

These explanatory figures can dangerously simplify the possible relations between intelligible forms that I claim to be what Plato wants to demonstrate by these examples of lies. However, all of these three examples: "good as the 
cause of evil", "hero, who has the courage over death, fear for death", "good man, who is self-sufficient, mourns for the lost" and "unjust man can be happy" shows contradictions between the ideas concerned.

We need to avoid these three kinds of lies not because they cause harm to the common good, but because of the confusion they cause in the soul: the confusion on knowing the forms and how forms articulate. On the contrary, there are some other lies whose falsehood are, according to Socrates, "not entirely pure" and are only "lies in words". These kinds of lies, in opposition to "lies in the soul", which refer to the three kinds of lies above, tell something true by lying. In the next section, I will try to demonstrate the criterion of the distinction between "lies in the soul" and "lies in words" as well as in order to show that the distinction between useful lies and harmful lies is not established on its utility to the community.

"Lies in words" and "lies in the soul"

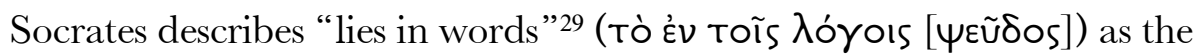
kind of lie which comes closest to the truth, and therefore this kind of lie is useful and does not deserve to be hated:

In the myth we were talking about, because of our not knowing where the truth stands in the past, we liken the lie to what is true as much as possible, do we make lie useful in this way ${ }^{30}$ ? $(382 \mathrm{c} 10-\mathrm{d} 3)$

The "lies in words" are not purely false, because the words "imitate the affection of the soul, which is later turned into an image" 31 (382b9-10). In other words, the "lies in words" indicate a kind of impure falsehood which contains certain truth. On the other hand, there is another kind of falsehood that is purely false in opposition to the "lie in words". That is what Socrates calls the "lie in the soul", that is, the "true lie" which introduces ignorance to the soul. The "true lie" is defined as "lies in the soul" or "falsehood in the psyche" by many commentators, in order to show its contrast with "lies in

\footnotetext{
${ }^{29}$ In certain translation, like EMLYN-JONES, PREDDY 2013, p. 215, "lie in words" is translated as "falsehood in words". I have clarified previously that the distinction between falsehood and lie is not drawn in Plato's Republic.

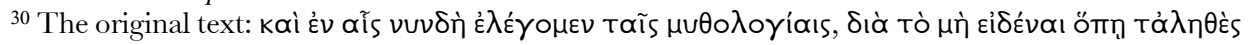

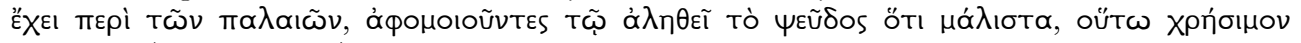

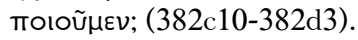

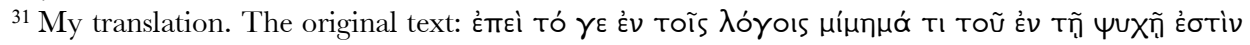

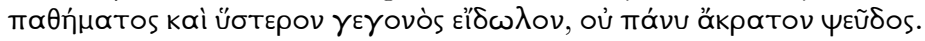


words" 32 . This contrast between two kinds of lies can only be marked in this passage which contains the three terms "true lie", "ignorance in the soul" and "lies in words" all together:

What would be most rightly called a true lie is the ignorance in the soul of the one who has been deceived. And the lie in words imitates the affection of the soul, which is later turned into an image ${ }^{33}$. (382b7-c1)

The "true lie" or "lies in the soul" is said to be hated by both gods and men (382a5); on the other hand, "lies in words" are the lies which can be useful in regard of a particular aim (382c-d3).

So Plato does draw a distinction between at least a pure falsehood and an impure falsehood. But what is the criterion that allows us to differentiate the pure falsehood from the impure one? According to Socrates, the falsehood is impure when it "imitates the affection of the soul," Since human soul can only be affected by thinking through intelligible forms, the impure falsehood imitates the thought of forms by producing an image. And then we need to ask: what exactly does the discourse imitate to correspond to the reality in order to be true, impurely false or truly false?

All creation of the poet is "three stages removed from reality"

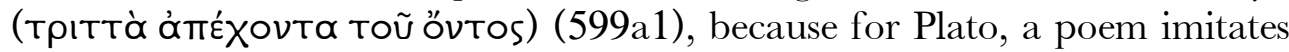
the image of the image of the reality. In Book X of the Republic, Socrates explains the different degrees of "being real" by distinguishing production of

\footnotetext{
32 Gill translates this opposition between these two kinds of lies into "falsehood in the psyche" and "falsehood in words", he claims that Plato's contrast between these two kinds of falsehood corresponds to the difference between "believing something which is in fact false" and "deliberate lying" (GILL 1993, p. 50). On the other hand, EmLYN-Jones, PREDDY 2013, p. LIX translate these into "falsehood in the soul" and "falsehood in words", and claim that the contrast corresponds to the distinction between the falsehood in the reality (falsehood in the soul) and the falsehood in words which can be useful. Demos claims that the contrast between "true lie" which, according to him, is characterized by "lie in the soul" and "lie in the words" corresponds to the difference between "self-deception" and "deception". "Lies in the words" for Demos is the kind of lie which the liar himself does not believe, in the contrary, "lies in the soul" is the kind of lie that liar, not only deceive others, but also himself (DEMOs 1960, pp. 588-589). The same contrast between two kinds of lie is translated and interpreted differently by Belfiore, who formulate the contrast in the passage of 382 b7-e10 into the opposition between "lies like truth" (lies in words) and "lies unlike truth"(true lies), and claims that the distinction between the two lies consists of the imitation of the truth (BELFIORE 1985, p. 49).

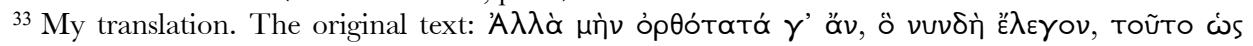

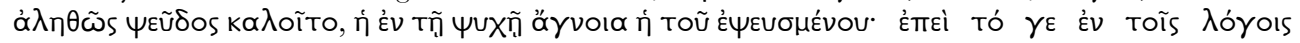

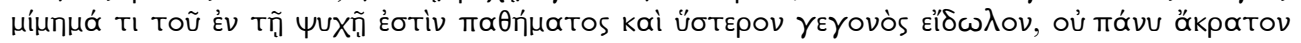

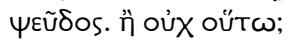


the craftsman, the painter and finally the poet. The craftsman imitates the real thing by fabricating the artefact; hence a bed is less real then the idea of bed, as Socrates says:

But if one were to say that the product of the bed-maker, or any other craftsman, is completely real, it's probable he would not be telling the truth ${ }^{34}$. (597a5-7)

Then, there is the creation of painter, which does not imitate the reality but the image of reality, so the painting is less real than the products of the craftsman, and is thus two stages removed from the reality since it is the "apparent object" instead of "real object" that it imitates:

What is the purpose of painting as regards individual objects? Is it to imitate what the real object is, or how its appearance looks? Is it the imitation of the apparent or the true? The apparent, he said ${ }^{35}$. (597e10-598a3)

Finally, there is the creation of the poet, which is said to be "three stages removed from reality", because the poem imitates the images of reality by representing them with words, which makes the poem the image of image of reality. Plato criticizes the poet, but he never states that all poems are lies, because poems, an imitation of an imitation of reality, can totally imitate the appearance of reality with or without knowing the reality. A good poet, according to Socrates, imitates with full knowledge, but since the audience does not necessarily have the knowledge to tell if the imitation is done with or without knowledge, all poets have the tendency and the capacity to create imitation without knowing the reality. As Socrates argues:

For the good poet, if he aspires to write well about whatever he does write about, must do so, they argue, with full knowledge, or he won't be able to. So we must investigate whether those who say this have been deceived in their meetings with such imitators, and when they see their works they don't realize that they're three stages removed from reality, and easy to create for someone who doesn't know the truth since they make apparent objects, not real ones ${ }^{36} \ldots$ (598e3599a3)

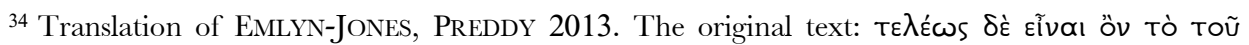

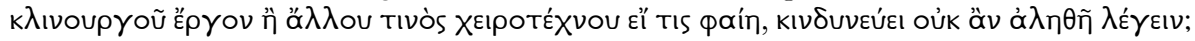

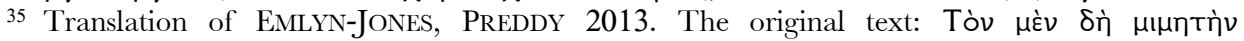

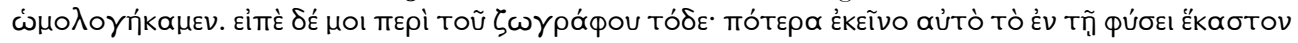

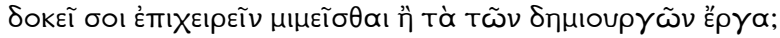

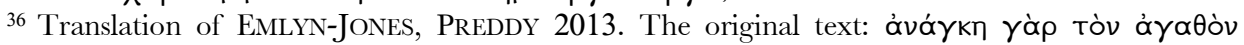

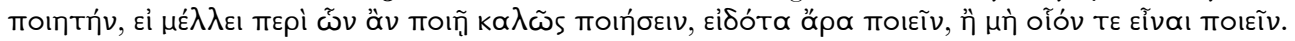

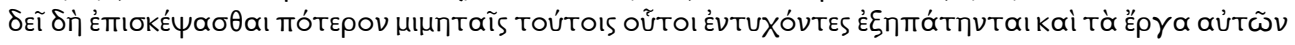


So the highest reality for Plato is the intelligible forms; then there are beings in the sensible world which participate in forms, and after that there are image of beings which participate in forms, image of their images, and so on. If the imitation of the discourse respects all the measure of its model, it is what Plato later describes in the Sophist as a "copy ${ }^{37}$ of reality". Since it is a copy of reality, it is a falsehood that tells something true about reality. Meanwhile, discourses that project images but do not respect the measure of its model and distort the images are false because they tell nothing true by projecting illusions (phantasia) $)^{38}$ of reality.

It is the resemblance between the imitation produced by the discourse and the reality that the discourse imitates that determine whether the discourse tells the whole truth, something partially true or nothing true. Nevertheless, the reality is not only the sum of elements, or in Plato's sense, the sum of each individual forms, but also the relations which articulate forms into one reality.

\section{The articulation of forms and the order of thought}

The relations shared by the forms (as the relation shared by the kinds) articulate the forms into a certain stable structure as Francis Macdonald Cornford describes ${ }^{39}$. Hence, according to Plato in the Sophist, forms and every being must be determined both by their own natures since they share "sameness" (Tò Taútòv) with themselves, by the relations they share with other and by "difference" (Өótepov) ${ }^{40}$ that distinguishes them from one another. Some

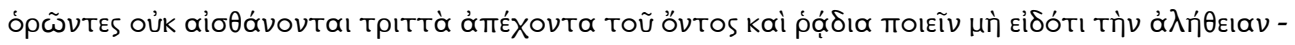

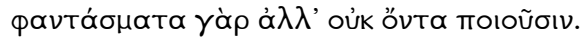

${ }^{37}$ In the Sophist, Plato distinguishes two forms of image: copy (eikon) and illusion (phantasia) in

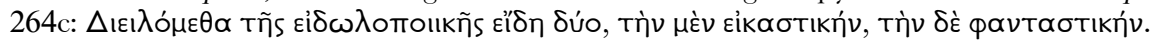

38 The word "phantasia" is translated differently according to different commentators, but what is important is the difference between "phantasia" and "phantasma" since both terms indicates "what appears to be". Teisserenc translates "phantasia" as "illusion" in order to distinguish from "the simple appearance" which, according to him, aims to correct the distortion of the image due to the distanced vision (Teisserenc 2010, p. 98). On the other hand, Crivelli translates "phantasia" as "appearance," in opposition to "apparition," his translation of phantasma. According to Crivelli, the distinction between "phantasia" and "phantasma" consists of the distinction of mental state and external things. Since "phantasia" for him is a perceptual belief, it can be a false representation of the external thing (CRIVELLI 2012, p. 260).

${ }^{39}$ Cornford interprets the division and assembly of forms as "the structure of the world of forms" and argues that the science of dialectic aims to seize this structure of the world of forms (CORNFORD 1935, pp. 268-272).

40 Translated by Rowe 2015, ad 255c. 
forms communicate while others do not, and this is how we define a being: by what it communicates and does not communicate with ${ }^{41}$. For example, Justice and Happiness are two beings (all forms are beings, so justice and happiness are also beings) in communication because they both communicate with the "goodness", that is, they share a sameness in relation to goodness, but they are also in non-communication since by definition Justice is not identical to Happiness.

This structure of forms is presented as an order in the thought, which decides whether our thoughts represented by discourse are true when the order is perfectly respected, or false when the discourse disrupts the order of thought and puts non-communicating forms together. This is the reason why the heroic story concerning the past is a lie, because the kind we constructed to determine what a hero is only communicates with "goodness" in the realm of the kind, by which it shares a relation with the kind "courage," while it shares no communication with "fear" for example. This is an extremely simplified example to analyze the dialectical relations between hero, courage and goodness, but Plato tries to manifest the distinction and to avoid associating justice with unhappiness or hero with fear in children's mind. Of course we can easily imagine a hero feeling fearful, but the point is: "hero", a kind that we can distinguish in order to refer to certain characteristics, is not a person, and a person is not just a "hero" since his or her being features multiple aspects.

When our capacity of intelligence has not fully developed to see things in their compound, we tend to understand them with simple labels: men, women, teacher, good person, bad person, etc. Since the whole discussion on lies in Book II and III of the Republic is placed in a context of the education for the children, we can see how Plato wishes to avoid the confusion brought about by the connection between forms because this kind of confusion destroys the structure that allows us to comprehend the world and to have true judgement in the first place and in addition to constitute or even reinsure this structure of thought. If educators do not make sense of the complexity, nor is the auditor capable of distinguishing, then these stories are what Plato call "lie in the

${ }^{41}$ The thesis of communication between forms gives later an explanation to the participation of kinds, and makes it clear that some kinds cannot participate some other kinds. Hence, if we associate kinds which do not communicate between them in a statement, the statement says necessarily something false. Dixsaut and Ambul propose that the participation of the kind "sameness" and "difference" is the intermediary thesis which allows us to solve the aporia caused by the theses of Heraclitus and the Parmenidean thesis in the Sophist (DiXsaut 1991; DiXsaut 2000, pp. 267-268; Ambuel 2013). 
soul" 42 because it puts contradiction in our thoughts (good is bad, hero is fearful, injustice makes happiness). These lies about gods, heroes and men are not judged to be lies because of their potential to harm. On the contrary, they are lies because their falsehood is even more fundamental since it involves, even attacks the order of the thought, which is the condition to establish the criterion to distinguish truth/falsehood.

Since the nature of every form is constant, so are the relations between them. Our thoughts, which reach out for reality, must respect these relations between forms in the organization of elements in our thought. The constant relations that articulate forms become the "order of thought" which articulate the elements in our thought in order to produce comprehensible content. The order of thought is not a normative order that obliges us to follow when we think; it rather structures our thought in the same way the reality is structured. That is why Plato insists on the fact that a "copy of intelligible reality", which is the best that human intelligence can have, is the imitation which respects the proportion $^{43}$. For example, when someone says that something is a model of a house, it doesn't mean that it is identical to the house itself. The model sometime doesn't even have the same color, and certainly not the same weight, but as a model, it means one thing: the relations between elements are respected. A model is always false for Plato in the sense that it is not the original, but a

\footnotetext{
42 The opposition between "lie in words" and "lie in the soul" allows us to remark the fact that there are at least two different falsehoods, and one of them is less "false" than the other. The "lie in the soul" is described as "deception in the soul about reality" (382b), but there exist different interpretations on the "lie in the soul". Demos claims that the "lie in the soul" is the kind of lie that one uses to "persuade himself to believe what he knows is not so", that is, a self-deception. And since a self-deception requires beliefs of something and its negation, the "lies in the soul" introduce a contradiction in our soul (DEMOS 1960 , p. 588). But for Gill, the "lie in the soul" is not necessary a self-deception, but one that introduces ignorance and concerns the most important thing, for example, gods (GILL 1993, p. 47). Defining the "lie in the soul" as self-deception does not explain why we believe something we believe is not what we believe. And if it is as Gill says, the importance of the object of the discourse determines whether this discourse is a lie in the soul or not, there can only be one kind of lie in the soul: the lie about gods. In the following part of my article, I will try to demonstrate why I disagree with these two interpretations on "lie in the soul".

${ }^{43}$ In the Sophist, Plato also discusses imitation and makes a comparison between the imitation of an artefact and the imitation of the discourse: "I see the likeness-making art as one part of imitation. This is met with, as a rule, whenever anyone produces the imitation by following the proportions of the original in length, breadth, and depth, and giving, besides, the appropriate colors to each part" $(235 \mathrm{~d} 7-235 \mathrm{e} 2$,

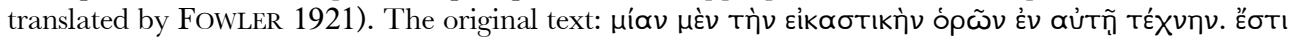

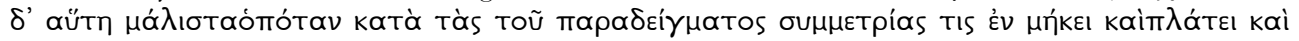

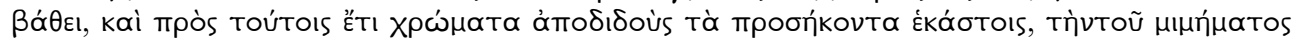

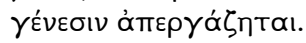


model turns into a lie when the proportion is modified or even distorted. We can therefore remark that there is indeed a difference in the falsehood of lies about gods, lies about heroes and men and the falsehood of "lies in words", but it is not the difference of types of falsehood, but the difference of degrees according to its level of distortion of the structure of forms, and hence the level of violation of the order of thought.

\section{The degrees of falsehood}

According to what Socrates discusses in the Republic, there can be false speech that "contains something true" 44 (377a5). Meanwhile, there is a kind of lie called the "true lie" or later "lies in the soul" that manifests a falsehood in its superlative sense. That is to say, for Plato, some false discourses can be true in a certain sense while other false discourses are "truly false" and hence have nothing to do with truth. Although Plato never proposes the degrees of falsehood, the intention to show that there is a difference in the falsehood can be marked by his distinction between "lies in words" and "lies in the soul", and the description on «likening the false to the true as much as possible» ${ }^{45}$. If Plato does think that there is a difference in the falsehood, then of what exactly does this difference consist which allows us to distinguish the "lies in words" from "lies in the soul" or the "lies like truth" from "lies unlike truth"? I propose the hypothesis as follows: Plato holds the idea of truth/falsehood which has different degrees, and three degrees of falsehood can be marked out in reference to its deviation from "reality", or more precisely, from the structure of forms.

True discourse tells things as they are; false discourse tells things different from what they are ${ }^{46}$. Plato doesn't affirm this explicit definition until the Sophist. Instead of claiming the existence of two senses of falsehood and consequently two criteria of truth/falsehood, I insist that there exists only one criterion of truth/falsehood in Plato's thought, particularly in the Republic, which is the correspondence between the discourse and reality.

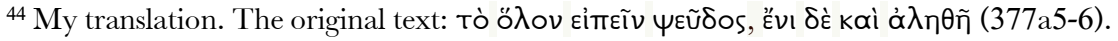

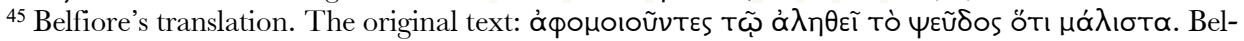
fiore argues that in Plato's Republic, this phrase is very similar to what Hesiod wrote in Theogony on the "lies like truth," and claims that the poets for Plato are those who create only the "lies unlike truth" (BELFIORE 1985).

46 This definition is found in the Sophist 263b: «The true one says thins as they are to be about you.

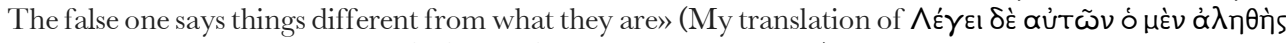

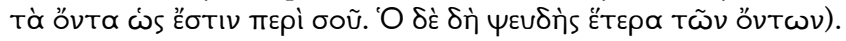


According to the same criterion of truth/falsehood, we differentiate at least two degrees of truth/falsehood corresponding to different degrees of reality. The distinction made in Republic between "lie in words" and "lie in the soul" already indicates two degrees of falsehood by confirming that "lie in words" tells both what is and what is not about reality, and that "lie in the soul" introduces only confusion and ignorance about what reality is. In other words, "lie in words" tells something false but also something true, because this kind of lie imitate the affection that soul can receive and create a virtual reality by respecting the order of forms. So, even if "lies in words" are still false, but this kind of lie does not compromise the order of forms which allows us to judge correctly. On the contrary, "lie in the soul" tells only what is false, because by compromising the order between forms, it compromise at the same time what allows us to make correct judgement, hence, we "possess and conserve the falsity" 47 (382b4) as Plato says.

Since Plato conceives reality in its different degrees, the correspondence to the different degrees of reality makes different degrees of truth/falsehood possible. Plato proclaims that the realm articulated by intelligible forms is the true reality, and this reality is constant and the source of our knowledge. And then, there are beings that participate in forms in the sensible yet volatile reality, which in this sense is less real than the first one. A false discourse tells something that the reality is not no matter it concerns the intelligible reality of forms or the sensible reality. But since the intelligible reality of forms is more real than the sensible reality, a discourse which respects the structure of forms but contains imaginary or unverifiable elements still tells something true about reality. The myth, certain poems, and the noble lie are considered to belong in this category, because they fabricate something in order to tell something true about intelligible reality which is articulated by forms. In the case of noble lie, there must be a noble truth that the noble lie reveals in order to be noble by saying:

Now all of you who are in the city are brothers, but during the creation the god mixed gold in the production of those of you who are competent to govern, for which reason they are worthy

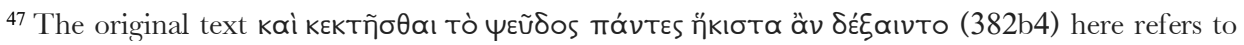
the passage where Plato explains the consequence of having the "lie in the soul": not only are we exempted from the truth, but also we conserve the falsity. What I try to argue in this article is that the only possibility for someone to conserve the falsity is the situation in which what the judgement relies on is compromised. In this situation, every time one produces a judgement, he or she is false because what is used for judging remains false.
} 
of the greatest respect, and he put silver into those who are auxiliaries, iron and bronze in farmers and other artisans ${ }^{48}$. (415a1-6)

The noble lie insists on two things: 1) all citizens share the same root and 2) the difference which separates us organizes us into one community with orders. The sameness that the participants share as a whole and the difference which makes multiplicity possible are the condition of possibility of the community. Therefore, the noble lie becomes a lie in the sense that it tells a story of the birth of the community which is not only a fiction, but is told as if it was a true story. Nonetheless, it reveals one fundamental truth, which allows not just an ideal community, but all communities that endure through the ages to be "generated" 49 .

On the other hand, when a discourse disrupts the order of thought by ignoring the articulation of forms, it tells nothing true and introduces only ignorance even if the elements in the discourse refers to names of real beings. This kind of discourse is what Plato calls "true lies," which are "lies in the soul" because not only does it not tell what is true, but also forbids us from knowing the intelligible reality. The three kinds of lies of poet mentioned above: lies about gods, lies about the past and lies about men, belong to this kind of falsehood.

So the lies mentioned in the Republic can be distinguished into two groups according to their degree of falsehood:

- First degree of falsehood: the fiction ${ }^{50}$, which contains imaginary elements in the discourse but respects the order of thought.

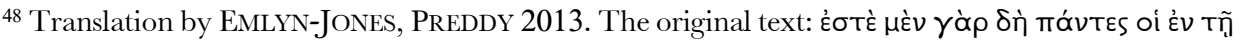

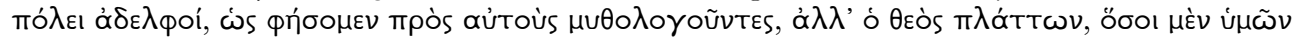

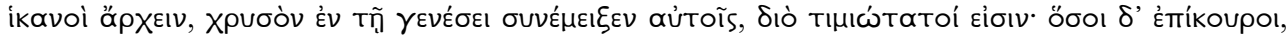

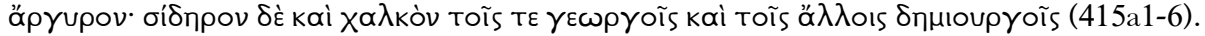

${ }^{49}$ Carmola analyse the term that Plato chose to say "noble lie" (gennaion pseudos) as a "well-born lie", because the word "gennaion" denote the sense of the root that generates things. I agree that the choice of the term "gennaion" relates the noble lie to the question of generation or the birth of something, but I disagree with Carmola's point of view, which interprets the question of noble lie as a question of the role familial background plays in politics (CARMOLA 2003, p. 40).

${ }^{50}$ Christopher Gill criticizes that certain authors translate the word "pseudos" into "fiction" in the passage where Socrates mentions stories about the distant past and the myth about which we do not know the truth. He claims that myths and stories about distant past are still false, and that we confound the problem by interpreting falsehood as fiction. But Gill also claims that the myth is a kind of falsehood that is "false in the form which they are presented, though ones which are made, presumably, "as like the true as possible" (382d). I use the word "fiction" here to indicate both myth and noble lie, which is a different kind of myth that the one who composes it wants to mask it factual form, and the word 
- Second degree of falsehood: the true lie, which implies a distortion in the order of thought, even if the elements mentioned in the discourse correspond to "real" personage or object in the sensible reality.

The falsehood can be useful not because it can persuade or it can consolidate the community, but because it can manifest truth in an expedient way. Some lies are true lies not because of the harm it can cause, but the total absence of truth and the presence of ignorance which consist of the distortion of the structure that forms articulate. Since the articulation of forms is the fundamental condition of possibility to create, understand and acquire knowledge and conception of truth, its distortion renders impossible the distinction between true and false, good and bad and so on. The distinction of the degrees of falsehood helps us understand better Plato's conception on truth/falsehood, and also his usage of metaphor, myths, poems and even the choice of dialogue as his form of writing. In certain circumstances, what reality is could be out of reach for human comprehension, or at least for most people to comprehend. And metaphor, myth or all false discourses of the first degree, with proper usage, can help us extend our comprehension of reality.

\section{Bibliography}

Altman, W.H.F. (2012), Plato the Teacher: The Crisis of the Republic, Lanham, MD.

Ambuel, D. (2013), «Difference in Kind: Observations on the Distinction of the Megista Gene», in B. Bossi, Th.M. Robinson (eds.), Plato's Sophist Revisited, Berlin-New York, 247-268.

Belfiore, E. (1985), «Lies Unlike the Truth’: Plato on Hesiod, Theogony 27», Transactions of the American Philological Association, 115, 47-57.

Carmola, K. (2003), «Noble Lying: Justice and Intergenerational Tension in Plato’s Republic», Political Theory, XXXI 1, 39-62.

Cornford, F.M. (1935), Plato's Theory of Knowledge: The Theaetetus and the Sophist, London.

Crivelli, P. (2012), Plato's Account of Falsehood. A Study of the Sophist, Cambridge-New York.

Demos, R. (1960), «Lying to Oneself», The Journal of Philosophy, 57, 588-595.

"fiction" denotes the kind of falsehood that conveys something true by imitating what is true as much as possible. 
Destrée, P. (2010), «Happiness, Justice, and Poetry in Plato’s Republic», Boston Area Colloquium in Ancient Philosophy. Proceedings, 26, 243-269.

Devereux, D. (2005), «Colloquium 7: The Relationship Between Justice and Happiness in Plato's Republic», Proceedings of the Boston Area Colloquium in Ancient Philosophy, XX $1,265-312$.

Dixsaut, M. (1991), «La négation, le non-être et l'autre dans le Sophiste», in P. Aubenque (ed.), Études sur le Sophiste de Platon, Napoli, 167-213.

Dixsaut, M. (2000), Platon et la question de la pensée, Paris.

Dombrowski, D. (2004), «On the Alleged Truth About Lies in Plato's Republic», Polis, XXI 1-2, 93-106.

Evlin-Jones, Ch., Preddy, W. (eds.) (2013), Plato’s Republic, Cambridge (Mass.)-London.

Fowler, H.N. (ed.) (1921), Plato, Theaetetus, Sophist, Cambridge (Mass.)-London.

Foster, M.B. (1938), «A Mistake of Plato's in the Republic: A Rejoinder to Mr. Mabbott», Mind, XLVII 186, 226-232.

Gill, Ch. (1993), «Plato on Falsehood - not Fiction», in Ch. Gill, T.P. Wiseman (eds.), Lies and Fiction in the Ancient World, Liverpool, 38-87.

Mabbott, J.D. (1937), «Is Plato’s Republic Utilitarian? », Mind, XLVI 184, 468-474.

Mouze, L. (2005), Le Législateur et le poète: Une interprétation des Lois de Platon, Villeneuve-d'Ascq.

Page, C. (1991), «The Truth About Lies in Plato's Republic», Ancient Philosophy, XI 1, 133.

Rowe, Ch (ed). (2015), Plato, Theaetetus and Sophist, Cambridge.

Teisserenc, F. (2010), Langage et image dans l'œuvre de Platon, Paris. 